\title{
Translanguaging in Multilingual Pre-Primary Classrooms in La Réunion: Reflecting on Inclusion and Social Justice in a French Postcolonial Context
}

\section{Pascale Prax-Dubois and Christine Hélot}

\section{Abstract}

This chapter explores the strategies and ideologies of two teachers who, each in their own way, try to mobilize the languages of young plurilingual learners (aged 3-4 and 5-6) in a pre-school situated in a marginalized area in La Reunion, a French island in the Indian Ocean and central hub of migration for families from neighbouring islands. We argue that translanguaging crossed with subaltern studies can be a powerful approach to deconstruct othering processes. Following this analysis, we propose a model for teacher education that includes three main objectives to rethink inclusion and social justice in a French post-colonial context.

\section{Keywords}

Translanguaging $\cdot$ Subaltern studies $\cdot$ Othering $\cdot$ Inclusion $\cdot$ Social justice

\section{Introduction}

According to Spivak (1985), Europe has asserted its position of sovereignty by 'othering' its former colonies. France is a good example of this process: it still holds many so called "overseas" territories where linguistic and cultural practices

\footnotetext{
P. Prax-Dubois $(\bowtie)$

Université de Strasbourg, Strasbourg, France

e-mail: pascale.dubois@etu.unistra.fr

C. Hélot Strasbourg, France

(C) The Author(s) 2020
}

J. A. Panagiotopoulou et al. (eds.), Inclusion, Education and

Translanguaging, Inklusion und Bildung in Migrationsgesellschaften, https://doi.org/10.1007/978-3-658-28128-1_4 
have been subordinated by the centralized education system, and where the principles of inclusive education (UNESCO 2009) are still not being implemented. French education is described by the latest PISA evaluations $(2018)^{1}$ as the most unequal among the richest OECD countries and is also well known for its ideological position on the national language, i.e. French, considered as the first and foremost priority for integration. This means that acknowledging and valuing the rich plurilingual repertoires of many students is a real challenge, both in metropolitan France and all the more so in overseas territories scattered throughout the world (Hélot and Erfurt 2016; Laroussi 2016; Muni Toke 2016).

This is the case of La Réunion, a small multilingual French island located in the South West of the Indian Ocean where the complexity of multilingual language practices has been the subject of a lot of research. Recognizing language practices within the theoretical framework of translanguaging means that schools should adopt a pedagogy moving from the separation of languages and from the priority of the French language to a pedagogy of "variation", as expressed by researchers in La Réunion (Prudent 2005; Lebon-Eyquem 2015; Georger 2005; Tupin and Wharton 2016). However, research addressing the exclusion of languages other than Creole, such as Malagasy and Mahoro-Comorian languages spoken by many children in Reunionese schools, is still lacking. Furthermore, teachers are not educated to understand the affordances of multilingual education, how linguistic and cultural diversity is linked to issues of social justice (Piller 2016; Prax-Dubois 2018) and how they could become agents of social change (Hélot 2007) even in such a highly complex context.

Our chapter is based on the analysis of data collected in two pre-primary classrooms, where two teachers implemented language awareness activities (Prax-Dubois 2018). Through a critical discourse analysis of the verbal interactions between children and their teacher and the transgressive lens of tranlanguaging pedagogy, which, as explained by García (2014), strives to make the voices of 'subaltern' subjects audible, we will describe the strategies developed by the two teachers, each in their own way, to mobilize migrant and indigenous students' plurilingual repertoires. More specifically, we will explain how they succeeded (or not) in promoting the inclusion of multilingual children in their teaching approach, through the deconstruction of the process of othering (Spivak 1985; Said 1978/2005). In other words, we will argue that specifically in post-colonial

\footnotetext{
${ }^{1}$ http://www.oecd.org/pisa/publications/PISA2018_CN_FRA_FRE.pdf.
} 
contexts such as La Réunion, teachers should be educated to understand the process of decolonizing language teaching in schools (López-Gopar 2016). We will conclude with propositions to (re)imagine a teacher education curriculum that includes the issue of linguistic diversity and social justice (Piller 2016) in postcolonial contexts.

\section{Context}

\subsection{Pre-School Education in France}

Pre-primary school in France is conceptualized as "école maternelle" and is well-known as a specific model of education for the early years. It became integrated into the primary sector as early as 1881. In September 2019, French president Macron decided it should become compulsory from age 3 in a bid to fight the high levels of child poverty in France. The latest curriculum dates from 2015. It applies to all écoles maternelles in mainland France and similarly in the overseas territories. Language awareness activities dealing with linguistic diversity are mentioned for children aged 4 to 6 , but only with "modest"2 ambitions, because the foremost objective is language acquisition "in all its dimensions", meaning the acquisition of different language competences in French. The formulation in French, "mobilisation du langage" expressed in the singular noun phrase hides an equivalence between language in general and the French language (Georger 2005, p. 7). This persistent ideology is all the more striking in La Réunion (and in other overseas French territories, see Hélot and Erfurt 2016) where Creole is the main language of communication and where many children speak diverse minoritized languages.

Research in French on plurilingualism in pre-school structures (crèches, kindergarten, or pre-schools) is scarce compared to publications in English (Hélot and Rubio 2013). For these authors, the language development of very young children in early childhood education and care (ECEC) is not only an educational issue but involves political choices, ideologies, and an ethical positioning. Hélot (2013, p. 52) describes bilingualism in the French context in terms of a dichotomy between elite bilingualism (with languages such as French and English for

\footnotetext{
2"Modeste" meaning limited, see: Programme d'enseignement de l'école maternelle: https://www.education.gouv.fr/pid25535/bulletin_officiel.html?cid_bo=86940.
} 
example) and mass or migrant bilingualism (when minoritized languages such as Turkish or Arabic are concerned), the difference residing in the ideological attribution of symbolic values to competing languages on the linguistic market (Bourdieu 1982). Thus, the availability of bilingual education in dominant languages and its nonexistence in minoritized languages are a further source of educational inequality (Hélot and Erfurt 2016) both in mainland France and all the more so in overseas territories (Muni Toke 2016).

\subsection{The Reproduction of Exclusion or Excluding Neighbours}

From a socio-historical point of view La Réunion is an insular society developed to "serve" France rather than model it (Bertile 2002) Its population has been European, Malgache, African and Asian from the beginning and its dynamism meant to lead to economic growth. It is a pluralistic society where the term "white" refers more to social class than to skin colour (Gerbeau 1997). The sudden access of the island to the post-modern era, since its transformation from an agricultural plantation economy into a tertiary economy in the 1980 s, did not impede the reproduction of inequalities.

The GDP per inhabitant is higher than in neighbouring islands but markedly lower than the GDP in mainland France and La Reunion now sees itself as a "donating Northern country" in relation to its poorer neighbours in the South (Bertile 2002). Indeed, the subsidies given to La Réunion by both mainland France and the European Union, are lower in Mayotte, a neighbouring overseas territory, therefore, it does not encourage solidarity between the different islands and it even fosters the development of stigmatizing stereotypes towards people who have no other choice but to move from a poorer island (Anjouan for example, which is a non-French island) to a richer one (Mayotte, which is French) and also from Mayotte and Madagascar to La Réunion. Such socio-political and economical injustice born out of the invention of collective identities (Said 1978/2005), and notions like "overseas" or "Francophonie", ends up creating socio-ethnic inequalities that have a major impact on the ideology of languages and knowledge transmission in schools (Fig. 1). 


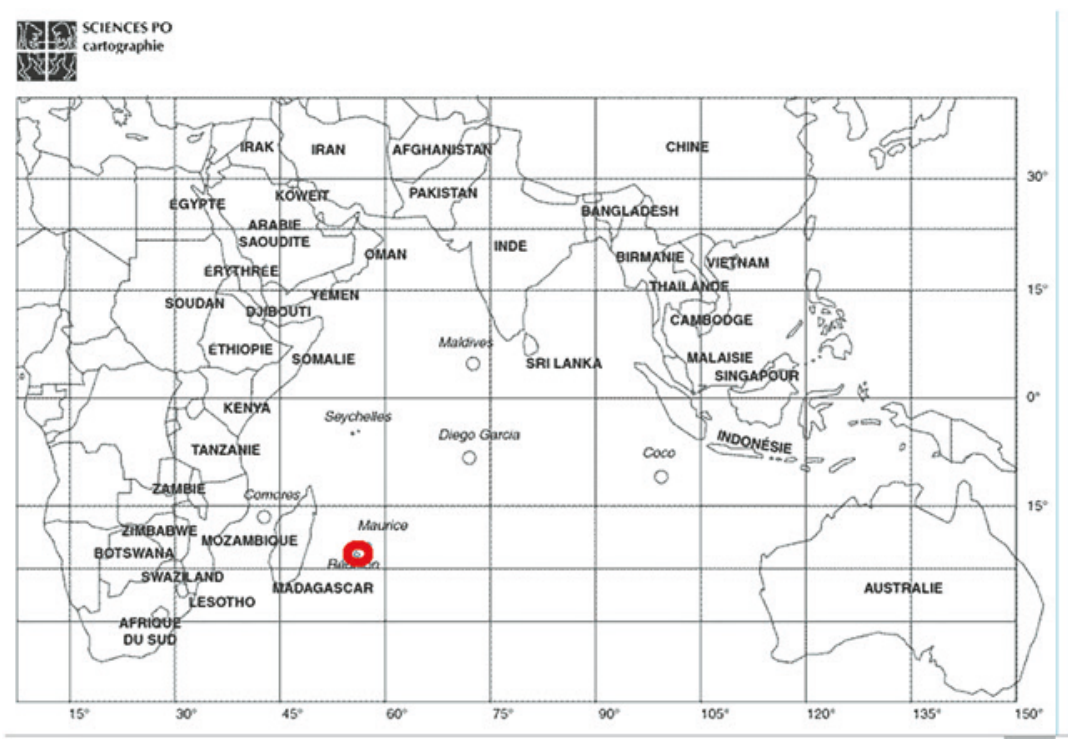

Fig. 1 Political map of the Indian Ocean. http://www.sciencespo.fr/

\subsection{Selective Plurilingualism in Schools in La Réunion}

Lebon-Eyquem (2015, p. 146) has recently shown ${ }^{3}$ that today, "two thirds of children aged 5 speak very little French or none at all". She also recorded languaging practices where it was impossible to distinguish clear profiles between speakers of French and speakers of Creole. But as stated above, the issue of the exclusion of languages other than Creole in education in La Réunion has hardly been addressed. In our doctoral research (Prax-Dubois 2018), we carried out a survey among 22 teachers working with newcomers in pre-primary, primary and secondary schools which revealed the diversity of languages brought into La Réunion by students identified as "allophones", ${ }_{4}$ as well as the

\footnotetext{
${ }^{3} 110$ children aged 5 were surveyed: their language interactions were recorded both in and outside of schools.

4"allophone" is the term used in the French curriculum to refer to children who do not speak French (circulaire 2012-141 du 2 octobre 2012). Hélot (2013) argues they should be called "bilingual".
} 
widespread presence of Shimaore and Malgache. While the teachers confirmed the rapid acquisition of Creole by their students, they also denounced the racism and solitude a great majority of these children suffer from. Their social marginalisation is most obvious in the erasure of their plurilingual repertoires which, as migrant languages from the Indian Ocean islands, remain largely invisible, and this even in the face of the recent popularity of the language awareness approach. ${ }^{5}$

We would like to argue that such language in education policies create an image of the other and her languages which relegates Creole and the other Indian Ocean languages to the domain of folklore (in the Gramscien sense). It feeds into colonial dichotomies (Prudent 2005; García 2014) and hides the complexity of such processes. This is why subaltern studies, according to us, allow for a new conceptualization of the relationships of power between languages and access to knowledge and underlying ideologies.

\section{$3 \quad$ Translanguaging and Subaltern Studies in Creole Speaking Contexts}

As Hélot (2013, p. 58) reminds us:

"Languages, in our societies, are always caught in processes of subordination and domination through the attitudes expressed towards their speakers" (our translation).

This is the reason why we propose to use both the transgressive perspective of translanguaging (García 2014, 2017) and that of subaltern studies with the concepts of othering and colonial difference, in order to highlight the ideologies that, in school and elsewhere, exclude a whole sector of the mainstream population through the production of images that maintain some groups at the service of others.

\footnotetext{
${ }^{5}$ See professional education for teachers on plurilingual Education offered by the CASNAV in La Reunion (Centre for the schooling of newcomer students): https://www.ac-reunion.fr/ casnav/formations-casnav.html.
} 


\subsection{Transglossic Spaces, Colonial Difference and Othering}

The colonial subject is constrained socially and symbolically by her language practices. It is as if the languages of the South could only be conceived through the vulnerability of their speakers who are seen as having no other opportunities but to master the language of the colonizers if they want their share of available resources. But this analysis lacks a finer observation of the discourse strategies as well as of the agency of teachers trying to implement multilingual approaches in their classrooms (Menken and García 2010), whether monolingual or legitimately "bilingual" classrooms. This is why García $(2014$, p. 108) proposed to replace the diglossic model by a transglossic one to describe "a societal stable, and yet dynamic, communicative network in the 21 st century, with many languages in functional interrelationship".

The prefix "trans" does not only translate the idea of crossing or mixing, but refers to transgressive theories of language (Pennycook 2007). Pedagogically, this implies that transglossic spaces should be opened up in classrooms, the voices of subaltern speakers should be heard and the colonial dimension of power relationships should be discussed (García 2014). In Creole speaking contexts, this means reframing linguistic diversity within the paradigm of transgressive and critical approaches so that the new spaces created allow for colonial injustice to be debated, in other words for three centuries of history to be uncovered (Prax-Dubois 2019b).

Colonial difference is the figure of speech through which coloniality conceives of the other as inferior, marked by a linguistic, cultural, moral or intellectual handicap and, therefore, inferior to the metropolitan standard (Mignolo 2000/2012; López-Gopar 2016). Situated at the intersection of Western, male, Christian, white thought with different approaches to local history and to naming the world, colonial difference is also an abstract place where power is exercised while being contested, a space where the subaltern ${ }^{6}$ knowledge of speakers is reinvested but also reified by hegemonic thinking (Mignolo

\footnotetext{
${ }^{6}$ Guha (1983/1999) was one of the first researchers to develop the field of subaltern studies and to question the national and colonial historiography, after he became aware of the social failure of independent India.
} 
2000/2012; López-Gopar 2016). Inspired by the work of Said (1978/2005) and his notion of orientalism, the concept of othering was defined as central to colonial discourse, which ambivalence lies in the reification of the colonized subject as both an object of desire and of derision expressed through political and discursive practices of racial and cultural hierarchy (Bhabha 1994).

Spivak (1985) proposed the notion of "new subaltern" and described the process of othering in colonial contexts as based on three dimensions: a) a permanent communication campaign informing people of their subordination, b) a systematic reference to the other as culturally and morally inferior, and c) the organisation of lack of access to knowledge being mediated by colonial agents who are not indigenous, therefore trustworthy. In this way, Spivak deconstructs the natural logic of "us vs them", explaining that formerly colonized post-war states could be regrouped in a single entity "the third world", which could then be maintained in a state of dependency and inferiority by the "first world", a global process she named "worlding".

What is the impact in La Réunion of this notion of "worlding" on "wording"? How are discursive spaces configured on a small island which belongs to both a franco-European entity and an Indian-Oceanic space situated between Mauritius and Madagascar, submitted to a capitalist economy since its control by La Compagnie des Indes and then by the French State and the European Union, but influenced by a profound Creole vision of the world? What can this mean for the education of children living in a region that feels the pressure of such geopolitical and socioeconomic factors? What does inclusion and social justice mean for young children in multilingual pre-schools in a French post-colonial context?

\subsection{Translanguaging and Critical Discourse Analysis}

To address these issues, we propose to analyse data gathered through non-participant observation of language awareness activities carried out in May and June 2013 in two pre-primary classrooms (children aged 3-4 and 5-6). The school is situated in one of the three poorest areas of the island. The area around the school is known for the high number of migrants coming from the neighbouring islands, more specifically Mayotte and other Comore Islands. This had resulted in some resident families sending their children to schools outside of this area. The school is suffering from lack of funding and an important turn-over of teachers (Prax-Dubois 2018). 
In order to understand these processes of intra-insular exclusion from a sociolinguistic point of view and to analyse the impact of socio-cultural factors on the way teachers apprehend their students' plurilingualism, we use the notion of translanguaging, "to observe closely the way in which people use language and base [their] pedagogical practices on that use, and not on what the school system says are valuable practices" (García 2007, p. 13). We also opted for a critical approach to discourse analysis with the aim to redress or lessen social inequalities (Fairclough, ([1995] 2013, pp. $10 \mathrm{f}$.) though highlighting the ideologies underlying language education implemented by teachers with their students. Critical discourse analysis brings to the fore whether students' voices as well as those of communities speaking othered languages are recognized and supported or whether they are excluded from the learning process (Cummins 2011). Therefore, this means that every teacher can act upon the redistribution of power within her own classroom (Hélot 2007, p. 123). Among the competences conceptualized by García and Li Wei (2014) and the ten grounded principles for decolonizing Primary English Language Teaching (López-Gopar 2016), we chose those more specific to teachers working at the pre-school level in a marginalized area of La Réunion. Our aim is to analyse whether it is possible in a French postcolonial context, to resist the process of othering produced by "the colonial difference discourse that positions Indigenous children as inferior and in need of help" (López-Gopar 2016, p. 199).

\section{$4 \quad$ Translanguaging Strategies in a Post-Colonial Context}

Our analysis does not oppose a competent teacher to one who would be less competent. Both teachers, each in their own way, wished to contest the language regime in place, and have in common an interest in their students' linguistic and cultural diversity and in using the pedagogical freedom allowed within a rather constraining national curriculum. Therefore, we are interested in the way each teacher managed human interactions and social inequalities according to their level of agency in a highly normalized sociolinguistic context. 


\subsection{Strategy $n^{\circ} 1$ : The Negotiation of the Curriculum Constraints}

The classroom is a strategic space for the negotiation of power relationships and Isabelle ${ }^{7}$ knows what she is doing in her bilingual class when she decides that on "French day", ${ }^{8}$ she will devote her French language lesson to the translation of "je t'aime" in all her students' languages, because mothers' day is approaching. She chose to carry out a plurilingual activity on the day when Creole is not supposed to be used. In other words, plurilingualism takes the place of additive bilingualism and Creole finds its own space among the other Indian-Oceanic languages thanks to the links created between the various languages used in the interactions.

Isabelle: maintenant il manque une langue qu'on n'a pas fait (Now there is one language missing)

[XXX]

Isabelle: en :: ? (Which one?)

Jean-André: MI AIM A OU

Kelly: mi aim a ou

Isabelle: en quelle langue? (Which language is it?)

Groupe d'élèves: EN CREOLE

Isabelle: alors / ça c'est facile / comment on dit ensemble? (So, this is easy/How do we say it all together?)

Groupe d'élèves: MI AIM A OU

Isabelle has no need of specific pedagogical support to carry out this research task, because "students can translanguage, as they find new information" and the activity connects them to their everyday life (García and Li Wei 2014; López-Gopar 2016), in this instance the preparation of mothers'day. She needs no pedagogical materials that would be using named languages, and in this way she helps her students to find their own voices and to develop critical thinking as was previously explained by Hélot (2007) writing about the Didenheim project.

Anna, the second teacher speaks neither Creole nor her students' languages as she has been recruited from mainland France. Therefore, she prefers to use a

\footnotetext{
${ }^{7}$ The names of the teachers have been changed for the purpose of the article.

${ }^{8}$ In this bilingual French/Creole pre-primary class of 5/6 year olds, the use of each language as a language of instruction is implemented every other day. In this instance, the language of schooling on that day was French.
} 
multilingual picture book presenting vocabulary in French, Shimaore and Malgache to encourage her newcomer students to express themselves. In the following extract, she tries to get her students to guess the word "tree" by saying it herself in Shimaore: "mwiri":

\footnotetext{
Anna: alors c'est quoi Abdou? ça c'est quoi Abdou / viens nous montrer / qu'est-ce que c'est mwiri? (So, what is it Abdou? What is that Abdou/ Come and show us/ what does "mwiri" mean?)

[Abdou se lève et montre l'image de l'arbre silencieusement] (Abdou stads up and shyly shows the picture of the tree)

Anna: SUPER / Comment on dit en français? (Great/ How do you say it in French?)

Groupe d'élèves: un A: RBRE (A tree)

Anna: un a: rbre (A tree)

Groupe d'élèves: un A: RBRE (A tree)

Anna: mwiri c'est arbre en / en shimaore / en maore // c'est bien: (Mwiri means tree in Shimaore, in Maore, good)
}

Anna considers her students' languages the same as she does French, as fixed entities that she wants them to master as a priority, through their lexical, phonological and morphosyntactic components. However, she does open up a plurilingual space through the use of a multilingual book that she discovers at the same time as her students. She really wants to give them some power through the opportunity to share their own expertise and also to have access to the translation of everyday lexical items in languages that remain excluded from the curriculum. In a certain way, even if the students are silent, they are cognitively active thanks to the allowed presence of their home languages.

\subsection{Strategy $n^{\circ}$ 2: The Mobilization of Inner Speech}

The fact that students remain silent in the classroom does not necessarily mean that they are inhibited or that they refuse to speak. Le Meur (2011) for example, explains that it is the third dimension of language beyond speaking and writing, "the living proof of what is unexpressed". When silence is active, it gives way to inner speech, and García and Li Wei (2014) have shown its centrality in translanguaging practices. ${ }^{9}$

${ }^{9}$ See also Prax-Dubois (2018, 2019a). 
When Anna uses the word tree in Shimaore (mwiri) to start questioning her students about its translation in French, she proposes that they compare both languages, French the language of schooling and Shimaore a minoritized language whose speakers are often discriminated against in La Réunion. This language-inquiry task does allow her in fact "to build translanguaging capacities and extend metalinguistic awareness" (García and Li Wei 2014, p. 122) but, beyond the correct answer, also demands that her students concentrate both on a cognitive and affective level. It seems as if the three students concerned do not interact, leaving their peers to occupy all the discursive space:

Anna [à Chaïma]: tu es d'accord? Chaïma Abdou vous êtes pas d'accord? Tu es d'accord ou pas? Inchati c'est ça ou pas? Inchati c'est ça mwiri? C'est ça mwiri?

Groupe d'élèves: non:

Anna (to Chaïma): Do you agree? Chaïma, Abdou, don't you agree? Do you agree or not? Inchati, Is it right or not? Inchati is that what mwiri means? Is this mwiri' The students' group: No

We know that "I don't know" and silences can discretely signify many hidden messages (López-Gopar 2016). But the repeated questioning of the teacher prevents her from becoming aware of the students' submerged language competence.

Isabelle interacts differently with her students because in her bilingual classroom she is used to questioning her students without any normative linguistic supports and, therefore, trusts them to manage the discursive space while at the same time watching out for her marginalized students to express themselves. And this is the reason why she is able to hear Zaïna who utters two barely audible words in the middle of the interaction in Creole:

- Groupe d'élèves: MI AIM A OU

- Zaïna [à voix basse]: nsouhou vendza

- The students' group: MI AIM A OU (I love you in reunionese Creole)

- Zaïna [in a low voice]: nsouhou vendza (I love you in Shimaore)

There was no need to question Zaïna to know what language she spoke, nor how she would translate a term. Waiting for her inner speech to let her feel like expressing herself, the teacher has opened a transgressive space giving time to her student to become aware of her peers' freedom of expression in Creole and to allow herself, albeit quite moved, to express her understanding of the world in Shimaore. 


\subsection{Strategy $n^{\circ}$ 3: Funds of Knowledge and Co-Learning}

The issue of role taking in teaching is central in educational sociolinguistics. Co-learning is defined by Li Wei (2014, p. 169) as "a process in which several agents simultaneously try to adapt to one another's behavior so as to produce desirable global outcomes that would be shared". In an inclusive multilingual classroom, students' funds of knowledge put into perspective with those of the teacher must be considered as vital resources because they are socio-historically defined (Moll et al. 1992; Li Wei 2014; López-Gopar 2016, p. 201).

In her bilingual class, Isabelle has a continuous interest in linguistic diversity and in the different ways the children express themselves in Creole and in French, therefore she also includes Shimaore in her pedagogy, for example in the case of Louis:

- on écoute bien Louis et on va répéter après Louis / d'accord? / Louis / dis nous je t'aime en maore (We listen carefully to Louis and we're going to repeat after Louis OK/Louis tell us I love you in Maore)

- Louis [portant un regard circulaire sur l'ensemble des élèves]: nousouvendza (Louis looks around the whole class at all the students)

- Isabelle: allez on répète (Go on, let's repeat)

- Groupe d'élèves: NOUSOUVENDZA

Through these interactions, Isabelle deconstructs the othering Louis could be subjected to as an "allophone" student. She behaves as a multilingual language and literacy teacher and gives us an example of what decolonizing language education could mean in a post-colonial pre-primary school, in the sense given by LópezGopar (2016, p. 196): "decolonizing primary English language teaching is a collaborative endeavor in which all of the actors produce knowledge and perform different roles".

Anna's pedagogical strategy is different. She also tries to avail of her students' funds of knowledge but she remains in charge of interactions in order to bring migrant students to use the French language and to understand its categorisation system:

Anna: alors c'est quoi Abdou? Ça c'est quoi Abdou / viens nous montrer / qu'est-ce que c'est mwiri? ((So, what is it Abdou? What is that Abdou/ Come and show us/ what does "mwiri" mean?)

[Abdou se lève et montre l'image de l'arbre silencieusement] (Abdu stands up and silently shows the picture of the tree) 
Anna: SUPER / Comment on dit en français? (Great/ How do you say it in French)

Groupe d'élèves: un A: RBRE (Student group: tree)

In other words, the teacher keeps in charge of the circulation of languages in the classroom, starting with the words in the multilingual book to move towards French, but the students do not perceive her interest in their own knowledge, and they need more time to understand the communicative situation. Furthermore, this activity (using the multilingual book) is not related to a social project but only to learning some vocabulary items by heart.

Anna, however, has enough courage to be aware of it and to change her didactic approach leaving aside the normative multilingual wordbook. Indeed, she finishes her lesson with a more natural conversation highlighting her students' linguistic practices out of school. But the necessary safe space for the students to express themselves freely is not solid enough and the friendly and well- intentioned questioning of the teacher, who is not aware of such pre-conditions, turns into a kind of cross-examination:

Anna: alors Abdou toi tu parles le maore à la maison? (So Abdou, what language do you speak at home?

[Abdou confirme d'un hochement de tête] (Abdou nods)

Anna: avec qui? avec papa avec maman avec tes frères et sœurs? (With whom? Your Dad, your Mum, your brothers and sisters?)

[Abdou infirme avec un mouvement de tête de droite à gauche] (Abdou denies turning his head from right to left)

Anna: Ben / Inchati / toi tu parles le maore? (Well, Inchati, do you speak Maore?)

[Inchati confirme d'un hochement de tête] (Inchati nods)

Anna: avec qui? (With whom?)

$[\ldots]$ (silence)

Anna: avec papa? (With Dad?)

All dialogues are socio-historically situated and give rise to ambivalent feelings towards the languages used (López-Gopar 2016). Without an awareness of and an inscription of these exchanges in the history of colonisation in the Indian Ocean, the identity investments of some students meet with the identity assignations of others and because these processes remain hidden the relationships of power reproduce themselves in the classroom. 


\section{$5 \quad$ Promoting Inclusion and Social Justice in French Postcolonial Pre-Primary Classrooms}

Including students' knowledge in the education agenda and promoting social justice means teacher education should start with a thorough reflexion on linguistic ideologies, the sharing of knowledge and evaluation (Shohamy 2006). Piller (2016, p. 127 f.) explains how submersive education which, according to UNESCO (2016) concerns $40 \%$ of students in the world accessing school knowledge through a language which is not theirs, imposes on these children a double challenge: "having to learn curriculum content through a new language while studying curriculum content in that language". This is the reason why, in our opinion, it beholds teacher educators both in mainland France and in its overseas territories, to make teachers aware of the three functions of the French language at school: the first being instruction, the second communication, both in the traditional sense given to the French language in the curriculum, and the third function should not be forgotten, subordination.

To illustrate our point, we look again at Anna and Isabelle's strategies in order to conceptualize a teacher education model which could put into perspective the three essential dimensions of the process of othering as elaborated by Spivak (1985): a) the systematic reference to the moral and cultural inferiority of targeted subjects that Mignolo (2000/2012) expressed in terms of colonial difference, b) the continuous reminder of their subordination in the name of this inferiority, and c) the colonial mediation which aim is to control access to resources and in this way leads to the maintenance of the allegiance of subaltern subjects. As a counterpoint to these three factors of subordination, we outline below three strategies developed to various degrees by the two teachers.

\subsection{Valuing and Promoting a Social Approach to Language}

Anna listens to her students with what she knows or she thinks she knows of the translation of the multilingual wordbook. Her beliefs, born out of her ideologies, lead to the children's silence while they are trying to figure out misunderstandings in the interaction. Isabelle, whose professional history is different, uses her didactic resources to listen to children with what she does not know. Because she can bring together her students' discourses and their understanding of the world, they become language teachers, too (López-Gopar 2016). 
It is tempting to link this approach to the language awareness approach. This approach allows for students to make links between different languages and gives emergent bilingual children an expert role in languages excluded from the curriculum. However, in France, this type of approach continues to insist on normalized languages as pre-existing the students' spontaneous language practices. Furthermore, valuing and legitimating family languages within the framework of language awareness is not sufficient (Coste 1995; Hélot 2007; Hélot and Rubio 2013). For example, García (2017, p. 267 f.) reminds us that too often "some multilingual awareness programs pay more attention to dominant languages than to their communities' own regional and immigrant languages", and do not sufficiently insist on the link between the present-day linguistic diversity and the history of colonisation in the world. Therefore, when educating teachers in La Réunion (or elsewhere), it is necessary to articulate language awareness with complementary approaches deconstructing the processes of subordination of minoritized groups.

\subsection{Reappropriating the History of Human Interactions}

Anna and Isabelle interpret the top-down language policies and formulate their own didactic approach according to the way they conceive their agency in relation to their perceptions of constraints, each of them in their own professional context (Prax-Dubois 2018). What Anna is lacking is the very strength of Isabelle, an understanding of micro and macro sociolinguistic and sociohistorical contexts and an awareness of the interdependence of these contexts at different levels. Her objective was to build "the common history of the class" (Hélot 2007, p. 158) with, as a background, a questioning of the separation of the world between East and West, geographical spaces which like languages, are "made by men" (Said 1978/2005, p. 17) and need to be disinvented (Makoni and Pennycook 2007).

To help teachers to understand these processes, García (2017, p. 277) proposes to move from the framework of language awareness to that of critical multilingual awareness and to integrate in the teacher education curriculum three essential competences: "awareness of plurilingualism and the importance of democratic citizenship, awareness of colonial histories and of imperialistic oppression and, awareness that language is socially created, and thus socially changeable". These main principles were at work in the Didenheim project in Alsace (Hélot 2007) which objectives were to challenge intolerance, racism and violence through the cultural rootedness of such processes (Hélot 2007) in order to decolonize 
them (Hélot 2019). Rehistorizing language education is also the main aim of the CEAR $^{10}$ project in Mexico (López-Gopar 2016), which showed how important it is to explore the historical dimension of the children's backgrounds as a key process to decolonize primary English language teaching. However, in the face of hierarchical control, ${ }^{11}$ it is also crucial for teachers to work collaboratively.

\subsection{A Critical Analysis of Mediation Processes: Who Says What, How and Why?}

For teachers to go against the grain, Spivak explains that they should be made aware of othering processes by looking at the "other" as a fighting partner for social justice rather than as an anthropological being. This reflection on the other is first of all a reflection to be carried out on oneself. It is based on the distance the teacher allows herself to take towards institutional discourses but also on the type of mediation one decides to implement as a counterpart to colonial mediation, this in order to give subaltern subjects access to resources. In other words, subaltern subjects should always collaborate to be more efficient in their transformative practices.

In La Reunion, Lebon-Eyquem (2018) has elaborated a hermeneutic approach for her master's course in language science. Through an analysis based on self-reflection and the rehistoricization of their biographical narratives, her students became beginner researchers. Her research shows the impact of their exchanges on the questioning and negotiation of their positioning towards plurilingualism. She noticed for example, how some of them managed to uncover the symbolic and ideological processes that hide in many speakers' representations of languages. Engaging in such a reflective process could be linked to educating students to critical discourse analysis. We would like to argue that this could help teachers to apprehend differently the socio-economic, historical, linguistic and educational phenomena which are more interdependent than what they conceive of by systematically asking: who says what and why? How does it impact my professional practice, my ideologies, those of my colleagues, of parents, of inspectors, of people visiting my classrooms, etc.? While keeping in mind that,

\footnotetext{
${ }^{10}$ Critical-Ethnographic-Action-Research project.

${ }^{11}$ Readers need to know that teachers in France are regularly "controlled" by inspectors whose role is to make sure the national curriculum is implemented.
} 
"language belongs to speakers rather than to nation states" (Hélot 2019, p. 94) and that once aware of this, everything is possible.

\section{Conclusion}

As educators working today in French schools either on the mainland or in overseas territories (the two contexts are intrinsically linked by their colonial past), it beholds us to implement inclusion and social justice meaningfully. This means that we cannot continue to ignore the double impact of colonial history and imperialistic oppression on school failure, two factors which according to García (2017) and Hélot (2019) are at the heart of most multilingual contexts today. Therefore, we have crossed research on subaltern studies with research on translanguaging and argued that both theories can provide us with the conceptual tools we need to deconstruct the paradigm of absolute efficiency that separates the world today, no longer in terms of what is fair or unfair but according to the survival of the fittest, or between former masters and new slaves (Camus 1951/2010). We believe this is possible from the very first years of early schooling, that is from the beginning of the appropriation of named languages, and the subordination of human beings to market driven societies.

\section{References}

Bertile, W. (2002). La Réunion et la coopération régionale [Reunion and regional cooperation]. Hermès, La Revue 1, 269-275.

Bhabha, H. K. (1994). The Location of Culture. London: Routledge.

Bourdieu, P. ([1982] 2007). Ce que parler veut dire, l'économie des échanges linguistiques [What it means to speak, the economics of language exchange]. Paris: Fayard.

Camus, A. (1951). L'homme révolté [The rebellious man]. Paris: Gallimard.

Coste, D. (1995). Éveil, veille, vigilance. Notions en Questions. Rencontres en didactique des langues [Awakening, watch, vigilance. Notions in Questions. Meetings in language didactics]. 1, 5-24.

Cummins, J. (2011). Foreword. In A.-M. de Mejia et C. Hélot (Ed.), Empowering teachers across cultures, Enfoques criticos, Perspectives croisées, Sprache, Mehrsprachigkeit und sozialer Wandel [Language, multilingualism, and social change]. (pp. 5-8). Frankfurt am Main: Peter Lang.

Fairclough, N. ([1995] 2013). Critical Discourse Analysis. New York: Routledge.

García O. (2007). Foreword. In S. Makoni \& A. Pennycook (Eds.), Disinventing and Reconstituting Languages (pp. xi-Xv). London: Multilingual Matters. 
García O. (2014). Countering the dial: transglossia, dynamic bilingualism and translanguaging in education. In R. Rubdy \& L. Alsagoff (Eds.), The global-local interface, language choice and hybridity, 100-118. Bristol: Multilingual Matters.

García O. (2017). Critical multilingual language awareness and teacher education. In J. Cenoz, D. Gorter, S. May (eds.), Encyclopedia of Language and Education 10 (pp. 263280). New York: Springer.

García O. \& Li Wei (2014). Language, Bilingualism and Education. New York: Palgrave Macmillan.

Georger, F. (2005). Approche du système de communication linguistique de certains enfants réunionnais. Réflexion sur le langage en situation de contact de langues. Travail d'étude et de recherche sous la direction de L. F. Prudent [Approach of the linguistic communication system of some Reunionese children. Reflection on language in language contact situations. Study and research work under the direction of L. F. Prudent.]. Université de La Réunion.

Gerbeau, H. (1997). Histoire oubliée, histoire occultée? La diaspora malgache à La Réunion: entre esclavage et liberté. [Forgotten History, Hidden History? The malagasy diaspora in La Réunion: between slavery and liberty]. In Ny fanandevozana teto madagasikara - L'esclavage à Madagascar - Aspects historiques et résurgences contemporaines, Actes du Colloque international sur l'Esclavage à Madagascar. Antananarivo: Musée d'Art et d'Archéologie - Institut de Civilisations de l'Université d'Antananarivo.

Guha, R. ([1983] 1999). Elementary aspects of peasant insurgency in colonial India. Delhi: Oxford University Press.

Hélot, C. (2007). Du bilinguisme en famille au plurilinguisme à l'école [From bilingualism in the family to plurilingualism at school]. Paris: L'Harmattan.

Hélot, C. (2013). Le développement langagier du jeune enfant en contextes bilingue et plurilingue: quels enjeux éducatifs pour les structures d'accueil de la petite enfance [Early Language Development in Bilingual and Plurilingual Contexts: What are the Educational Challenges for Early Childhood Services?]. In C. Hélot., M.N. Rubio (Eds.), Développement du langage et plurilinguisme chez le jeune enfant (pp. 41-60). Toulouse: Editions Erès.

Hélot, C. (2019). Ofelia García: A Visionary Thinker. Journal of Multilingual Education Research 9, 79-98. Available online at: https://fordham.bepress.com/jmer/volç/iss1/2.

Hélot, C. \& Erfurt, J. (2016). L'éducation bilingue en France. Politiques linguistiques, modèles et pratiques [Bilingual education in France. Language policies, models and practices]. Limoges: Lambert-Lucas.

Hélot, C. \& Rubio, M.-N. (2013). Introduction. In C. Hélot \& M.N. Rubio (Eds.), Développement du langage et plurilinguisme chez le jeune enfant [Language Development and Multilingualism in Young Children]. (pp. 15-40). Toulouse: Editions Erès.

Laroussi, F. (2016). Pour quand une éducation plurilingue à Mayotte? [When will there be a multilingual education in Mayotte?]. In C. Hélot, J. Erfurt (Eds.), L'éducation bilingue en France. Politiques linguistiques, modèles et pratiques (pp. 129-143). Limoges: Lambert-Lucas.

Lebon-Eyquem, M. (2015). Quelle prise en compte par l'école réunionnaise de la diversité des profils linguistiques de ses élèves? [How does the Réunionese school take into account the diversity of the linguistic profiles of its students?]. Cahiers de linguistique. Revue de sociolinguistique et de sociologie de la langue française 41(2), 139-156. 
Lebon-Eyquem, M. (2018). Biographie langagière, récit d'apprentissages multiples, découverte de la complexité linguistique. Une plongée dans le système réunionnais [Language biography, story of multiple learning, discovery of linguistic complexity. A dive into the Reunionese system]. In B. Idelson, I. Babou (Eds.), Lire des vies. L'approche biographique en lettres et en sciences humaines et sociales (pp. 35-59). Saint Denis de La Réunion: Presses Universitaires Indianocéaniques.

Le Meur, C. (2011). Le silence du texte. La fondation du langage adressé [The silence of the text. The foundation of addressed language]. Poétique 165(1), 73-89.

Li Wei (2014). Who's Teaching Whom? Co-Learning in Multilingual Classrooms. In S. May (Ed.), The Multilingual Turn: Implications for SLA, TESOL, and Bilingual Education (pp. 167-190). New York: Routledge.

López-Gopar, M. E. (2016). Decolonizing primary English language teaching. Bristol: Multilingual Matters.

Makoni, S. \& Pennycook, A. (2007). Disinventing and reconstituting languages. Disinventing and reconstituting languages. Clevedon: Multilingual Matters.

Menken, K. \& García, O. (2010). Introduction. In K. Menken \& O. García (Eds.), Negotiating Languages Policies in Schools. Educators as policymakers, (pp. 1-10). New York: Routledge.

Mignolo, W. D. (2012). Local Histories. Global Designs. Coloniality, subaltern knowledges, and border thinking. Princetown: Princetown University Press.

Moll, L. C., Amanti, C., Neff, D., Gonzalez, N. (1992). Funds of knowledge for teaching: using a qualitative approach to connect homes and classrooms. Theory Into Practice 21(2), 132-141.

Muni Toke, V. (2016). Les politiques éducatives bilingues dans les Outre-mer: situation postcoloniale et rhétorique de l'expérimentation [Bilingual education policies in Overseas France: the post-colonial situation and the rhetoric of experimentation]. In C. Hélot \& J. Erfurt (Eds.), L'éducation bilingue en France. Politiques linguistiques, modèles et pratiques (pp. 45-51). Limoges: Lambert-Lucas.

Pennycook, A. (2007). Global Englishes and Transcultural Flows. London: Routledge.

Piller, I. (2016). Linguistic Diversity and Social Justice. An introduction to applied sociolinguistics. Oxford: Oxford University Press.

Prax-Dubois, P. (2018). La formation des enseignants du primaire à La Réunion. Comment construire une éducation pluril ingue? [Training of primary school teachers in Reunion Island. How to build a multilingual education?]. Thèse de doctorat sous la direction de Hélot, C., Laroussi, F. Université de Strasbourg.

Prax-Dubois, P. (2019a). L'exclusion langagière dans les classes superdiverses en outre-mer français. Silences, maillages et perspective inclusive dans l'océan Indien [Language exclusion in the French Overseas Superdiverse Classes. Silences, meshing and an inclusive perspective in the Indian Ocean]. Revue des sciences de l'éducation de McGill 54/2, 326-348.

Prax-Dubois, P. (2019b). Décoloniser le multilinguisme à l'école française. Pour une pédagogie rhizomatique et transgressive [Decolonizing multilingualism in French schools. For a rhizomatic and transgressive pedagogy]. Cahiers internationaux de sociolinguistique $16,43-74$.

Prudent, L.-F. (2005). Interlecte et pédagogie de la variation en pays créoles [Intercollection and pedagogy of variation in Creole countries]. In L.-F. Prudent, F. Tupin et S. 
Wharton (Eds.). Du plurilinguisme à l'école. Vers une gestion coordonnée des langues en contextes éducatifs sensibles (pp. 359-378). Berne: Peter Lang.

Said, E.W. (1978/2005). L'orientalisme. L'Orient créé par l'Occident [Orientalism. The East created by the West]. Paris: Seuil.

Shohamy, E. (2006). Language Policy, Hidden Agendas and New Approaches. London: Routledge.

Spivak, G. C. (1985). An essay in reading the archives. History and theory 24(3), 247-272.

Tupin, F. \& Wharton, S. (2016). Le plurilinguisme réunionnais: entre instabilité des politiques linguistiques et inadéquation des approches didactiques [Plurilingualism in Reunion Island: between instability of language policies and inadequacy of didactic approaches]. In C. Hélot \& J. Erfurt (Eds.). L'éducation bilingue en France: Politiques linguistiques, modèles et pratiques [Bilingual Education in France: Language Policies, Models and Practices] (pp. 100-117). Limoges: Lambert-Lucas.

UNESCO (2009). Principes directeurs pour l'inclusion dans l'éducation [Guidelines for Inclusion in Education]. https://unesdoc.unesco.org/ark:/48223/pf0000177849_fre. Accessed: September 12th 2019.

UNESCO (2016). Comment apprendre quand on ne comprend pas? [How can you learn when you don't understand?]. https://unesdoc.unesco.org/ark:/48223/pf0000243713_ fre. Accessed: October 4th 2019.

Open Access This chapter is licensed under the terms of the Creative Commons Attribution 4.0 International License (http://creativecommons.org/licenses/by/4.0/), which permits use, sharing, adaptation, distribution and reproduction in any medium or format, as long as you give appropriate credit to the original author(s) and the source, provide a link to the Creative Commons license and indicate if changes were made.

The images or other third party material in this chapter are included in the chapter's Creative Commons license, unless indicated otherwise in a credit line to the material. If material is not included in the chapter's Creative Commons license and your intended use is not permitted by statutory regulation or exceeds the permitted use, you will need to obtain permission directly from the copyright holder.

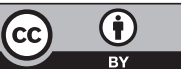

